\title{
KONTRIBUSI GURU PENDIDIKAN AGAMA ISLAM (PAI) DALAM MENGEMBANGKAN SELF CONTROL SISWA DI SMA DUA MEI CIPUTAT
}

\author{
Laila Nur Habibah \\ Institut Ilmu Al-Qur'an (IIQ) Jakarta \\ laila.habibah@gmail.com \\ Siti Saniah \\ Institut Ilmu Al-Qur'an (IIQ) Jakarta \\ $\underline{\text { Saniah33@gmail.com }}$ \\ Irmawati \\ Institut Ilmu Al-Qur'an (IIQ) Jakarta \\ Iir.irmawati23@gmail.com
}

\begin{abstract}
This study aims to describe the contribution of Islamic Religious Education teachers in developing self-control in students at SMA Dua Mei Ciputat. This type of research is a type of qualitative or non-statistical research. Qualitative research is an intensive search using scientific procedures to produce narrative conclusions both written and oral based on analysis of certain data. Sources of data in research are the subjects from which data can be obtained. The research subject was the Islamic Religious Education (PAI) teacher at SMA Dua Mei. According to Averill in M. Ghufron, self control is called personal control, namely behavior control, cognitive control and decision control. The conclusion of this study is that the teachers of Islamic Religious Education (PAI) at SMA Dua Mei Ciputat are sufficient to contribute in developing self-control for students at SMA Dua Mei Ciputat. It can be seen that the PAI teacher has tried to develop every aspect of selfcontrol, namely the cognitive control aspect by providing more information about knowledge about Islam by integrating PAI learning material with the surrounding conditions, then the control aspect. The behavior (behavior control) of Islamic Education teachers provides habituation both to students inside and outside the classroom, such as discipline, accustoming students to praying in congregation, as well as aspects of decision control, where students are given the opportunity to have an opinion during discussions conducted with the guidance of the PAI teacher. PAI teachers also provide guidance and direction to students who violate school regulations. From the various contributions of Islamic Religious Education (PAI) teachers, it is certainly very influential on the development of student self-control, this can be seen from the habituation applied by Islamic Religious Education (PAI) teachers can provide positive changes to students, such as students having awarenessin worshiping and participating in religious activities without coercion from the PAI teacher, students have self-confidence, and make students moreinterested in deepening the knowledge of Islam.
\end{abstract}

Keywords: Teacher Contribution, Islamic Education and Self-Control 


\begin{abstract}
ABSTRAK
Penelitian ini bertujuan untuk mendeskripsikan kontribusi guru Pendidikan Agama Islam dalam mengembangkan self control (kontrol diri) pada siswa di SMA Dua Mei Ciputat. Jenis Penelitian yang digunakan merupakan jenis penelitian kualitatif atau bersifat non statistik. Penelitian kualitatif adalah penelusuran secara intensif menggunakan prosedur ilmiah untuk menghasilkan kesimpulan naratif baik tertulis maupun lisan berdasarkan analisis data tertentu. Sumber data dalam penelitian adalah subjek dari mana data dapat diperoleh. Subjek penelitian adalah guru Pendidikan Agama Islam (PAI) SMA Dua Mei. Menurut Averill dalam M. Ghufron menyebutkan kontrol diri dengan sebutan kontrol personal yaitu kontrol perilaku (behavior control), kontrol kognitif (cognitive control) dan mengontrol keputusan (decision control). Kesimpulan dari penelitian ini adalah guru Pendidikan Agama Islam (PAI) di SMA Dua Mei Ciputat sudah cukup berkontribusi dalam mengembangkan self control (kontrol diri) siswa di SMA Dua Mei Ciputat. Hal ini dapat dilihat bahwa guru PAI sudah berupaya dalam mengembangkan setiap aspek dalam self control (kontrol diri) yaitu Aspek kontrol pengetahuan (cognitive control) dengan memberikan informasi lebih mengenai pengetahuan tentang agama Islam dengan cara mengintegrasikan materi pembelajaran PAI dengan keadaan sekitar, kemudian aspek kontrol perilaku (behavior control) guru PAI memberikan pembiasaan baik kepada siswa di dalam maupun di luar kelas, seperti disiplin, membiasakan siswa shalat berjamaah, serta aspek kontrol keputusan (decision control) yaitu siswa diberi kesempatan untuk berpendapat pada saat diskusi yang dilakukan dengan bimbingan guru PAI, guru PAI juga memberikan bimbingan dan arahan kepada siswa yang melanggar peraturan sekolah. Dari berbagai kontribusi guru Pendidikan Agama Islam (PAI) tentu sangat berpengaruh terhadap perkembangan self control (kontrol diri) siswa, hal ini dapat dilihat dari pembiasaan yang diterapkan oleh guru Pendidikan Agama Islam (PAI) dapat memberikan perubahan yang positif terhadap siswa, seperti siswa memiliki kesadarandalam beribadah dan mengikuti kegiatan keagamaan tanpa ada paksaan dari guru PAI, siswa memiliki rasa percaya diri, dan membuat siswa menjadilebih tertarik untuk memperdalam ilmu agama Islam.

Kata kunci: Kontribusi Guru, PAI dan Kontrol Diri
\end{abstract}




\section{PENDAHULUAN}

Guru menjadi sumber yang dapat menghantarkan para siswanya menuai hasil yang diharapkan. Menurut UU SISDIKNAS No.20 Tahun 2003 tentang Guru dan Dosen, yang dimaksud guru adalah pendidik profesional dan tugas utamanya mendidik, mengajar, membimbing, mengarahkan, melatih, menilai dan mengevaluasi peserta didik pada pendidikan anak usia dini jalur pendidikan formal, pendidikan dasar dan pendidikan menengah.

Masa transisi anak-anak menuju dewasa menghadapkan mereka kepada situasi yang dewasa. Pada masa ini konflik yang terjadi dapat menyebabkan timbulnya perilaku-perilaku yang tidak sewajarnya dan apabila tidak terkontrol akan menjadi kenakalan remaja (Ivong Rusdiyanti: 2019).

Menurut Vina (2018) dalam bukunya yang berjudul Kenakalan Remaja dan Penanggulangannya, remaja yang banyak melakukan tindakan kenakalan biasanya berusia 15-19 tahun, dibanding usia-usia lain. Di usia itulah remaja paling banyak melakukan tindakan kenakalan. Biasanya anak-anak seperti itu kurang memiliki pengendalian diri. Mereka tidak dapat mengatur dirinya sendiri dan suka meremehkan orang lain.

Senada, Ramadona (2019) menguraikan bahwa remaja sebagai individu sedang berada dalam proses berkembang atau menjadi (becoming), yaitu berkembang kearah kematangan atau kemandirian. Remaja memerlukan bimbingan karena mereka masih kurang memiliki pemahaman atau wawasan tentang dirinya dan lingkungannya serta pengalaman dalam menentukan arah kehidupannya untuk mencapai kematangan.

Dunia pendidikan dewasa ini menghadapai berbagai masalah yang sangat komplek yang perlu mendapatkan perhatian, salah satunya adalah masalah kesiswaan yang menyebabkan menurunnya tata krama sosial dan etika moral dalam praktek kehidupan sekolah yang mengakibatkan sejumlah peristiwa negatif yang merisaukan masyarakat. Peristiwa tersebut antara lain semakin maraknya berbagai penyimpangan norma kehidupan agama dan sosial yang terwujud dalam bentuk kenakalan siswa di sekolah seperti, kurang hormat kepada guru dan karyawan, kurang berdisiplin terhadap waktu dan tidak mengikuti peraturan, perkelahian antar pelajar, merokok di sekolah dan lain sebagainya.

Kenakalan menunjuk pada perilaku yang berupa penyimpangan atau pelanggaran pada norma yang berlaku. Ditinjau dari segi hukum, kenakalan merupakan pelanggaran terhadap hukum yang belum bisa dikenai hukuman pidana sehubungan dengan usianya. Perilaku meyimpang pada remaja pada umumnya merupakan kegagalan sistem kontrol diri terhadap impuls-impuls yang kuat dan dorongan-dorongan instingtif. Impuls-impuls, dorongan primitif dan sentimen tersebut disalurkan lewat perilaku kejahatan, kekerasan agresi dan sebagainya yang dianggap mengandung nilai lebih oleh kelompok remaja tersebut.

Pada hari senin tanggal 7 September 2019, peneliti melaksanakan kegiatan pratik Pengenalan Lapangan Persekolahan II (PLP II) di SMA Dua Mei Ciputat. Sebelum mendapatkan tugas mengajar di kelas, guru Pendidikan Agama Islam (PAI) SMA Dua Mei meminta untuk mengamati pembelajaran di kelas XII IPA 1 guna memberikan pengetahuan mengenai pembiasaan apa saja yang dilakukan sebelum dan ketika proses belajar mengajar. Selain melaksanakan kegiatan praktik mengajar penulis juga menjadi guru piket, membantu mengawasi ujian, 
membantu kegiatan program organisasi siswa dan membantu kegitan-kegitan yang ada di sekolah.

Berdasarkan observasi yang dilakukan oleh peneliti di SMA Dua Mei Ciputat, peneliti menemukan ada tiga orang siswa yang ikut melakukan aksi mahasiswa yang menggelar demonstrasi di gedung DPR dan MPR pada tanggal 19 September 2019, hal ini diketahuioleh pihak sekolah dari laporan polisi yang mengawasi aksi demonstrasi mahasiswa tersebut. Pada tanggal 20 September 2019 ke tiga siswa tersebut disidang dan diberikan bimbingan bahwa apa yang telah dilakukannya adalah tindakan yang salah. Pada saat itu peneliti melihat guru Pendidikan Agama Islam (PAI), Wakasek bagian kesiswaan dan Wakasek bagian kurikulum yang memberikan bimbingan kepada ke tiga siswa tersebut. Peneliti melakukan pengamatan selama proses kegiatan pratik Pengenalan Lapangan Persekolahan II (PLP II) di SMA Dua Mei Ciputat yaitu, peneliti menemukan bahwa guru PAI di SMA Dua Mei banyak berkontribusi dalam kegiatan keagamaan di sekolah, guru PAI di SMA Dua Mei juga sangat memperhatikan kedisiplinan siswa, hal ini dapat dilihat ketika guru PAI menjadi guru piket setiap hari rabu dan ketika kegiatan belajar mengajar di dalam kelas. Peneliti melihat bahwa guru PAI di SMA Dua Mei sangat tegas ketika ada siswa yang datang terlambat, siswa diberi hukuman dengan hafalan surat-surat pendek dan berdiri beberapa menit untuk memberikan kesadaran kepada siswa tersebut.

Hasil pengamatan tersebut penulis tertarik untuk mengetahui bagaimana mengembangkan self control (kontrol diri) dengan pembiasaan serta kegiatankegiatan keagamaan yang diupayakan guru Pendidikan Agama Islam (PAI) di SMA Dua Mei Ciputat. Dari Hasil pengamatan tersebut peneliti ingin melakukan penelitian dengan judul "Kontribusi Guru Pendidikan Agama Islam dalam Mengembangkan Self Control (Kontrol Diri) Siswa di SMA Dua Mei Ciputat".

\section{METODE PENELITIAN}

Penelitian yang penulis lakukan merupakan jenis penelitian kualitatif atau bersifat non statistik. Penelitian kualitatif adalah penelusuran secara intensif menggunakan prosedur ilmiah untuk menghasilkan kesimpulan naratif baik tertulis maupun lisan berdasarkan analisis data tertentu (Wayan Suwendra: 2018: 7). Dalam penelitian kualitatif digunakan teknik observasi terlibat langsung atau riset partisipatori, pada praktiknya peneliti akan melakukan review terhadap berbagai dokumen atau foto-foto.

Penelitian kualitatif ditunjukkan untuk untuk memahami fenomenafenomena sosial dari sudut atau prespektif partisipan. Penelitian kualitatif dalam pandangan Nana Syaodih (2013) yaitu mengkaji prespektif partisipan dengan multi strategi, strategi-strategi yang bersifat interaktif seperti observasi langsung, observasi partisipasif, wawancara mendalam, dokumen- dokumen dan lainnya. Penelitian ini menggunakan pendekatan dekriptif, penelitian deskriptif adalah penelitian yang berusaha mendeskripsikan suatu gejala, peristiwa, kejadian yang terjadi, saat sekarang. Penelitian deskriptif memusatkan perhatian pada masalah aktual sebagaimana adanya pada saat penelitian berlangsung. Melalui penelitian deskriptif, peneliti berusaha mendeskripsikan peristiwa dan kejadian tanpa memberikan perlakuan khusus (Juliansyah: 2011: 34).

Metode penelitian yang digunakan dalam penelitian ini adalah metode kualitatif yang menggunakan pendekatan deskriptif. Penelitian kualitatif 
disebutkan oleh Zainal Arifin (2014: 140) adalah suatu proses penelitian yang dilakukan secara wajar dan natural sesuai dengan kondisi objektif di lapangan tanpa adanya manipulasi, serta jenis data yang dikumpulkan terutama data kualitatif.

\section{HASIL PEMBAHASAN}

\section{A. Analisis Kontribusi Guru Pendidikan Agama Islam (PAI) dalam Mengembangkan Self Control (Kontrol Diri) Siswa di SMA Dua Mei Ciputat}

Salah satu tujuan SMA Dua Mei adalah menghasilkan lulusan yang cerdas dalam intelektual (IQ), emosional (EQ), dan Spiritual (SQ), hal ini berarti sekolah tidak hanya menghasilkan lulusan yang cerdas dalam bidang ilmu pengetahuan dan teknologi saja, namun sekolah juga ingin menghasilkan lulusan yang memiliki kecerdasan emosi yang baik serta kokoh dalam iman dan takwa nya. Maka dari itu hal-hal yang berkaitan mengenai kecerdasan emosional dan kecerdasan spiritual juga dilakukan sekolah untuk mencapai tujuan. Mengembangkan kecerdasan emosional juga sangat diperlukan dalam upaya untuk pengendalian diri. Penerapan nilai-nilai keagamaan di SMA Dua Mei Ciputat ini juga menjadi sesuatu yang diperhatikan untuk menghasilkan lulusan yang sesuai dengan tujuan SMA Dua Mei Ciputat. Penerapan nilai-nilai keagamaan di sekolah SMA Dua Mei tidak hanya diterapkan di dalam kelas saja tetapisekolah juga melakukan penerapan nilai-nilai keagamaan di luar kelas.

"...Ketercapaian kurikulum pemerintah itu yang pedoman pertama yah, yang kedua ada target sekolah ini harus ada nilai plus dari sisi religiusnya. Jadi kalau hanya kita punya kurikulum sesuai dengan aturan pemerintah pembelajaran PAI seperti ini nah kita harus ada lebihnya..."

Peneliti menganalisis bahwa kegiatan pembelajaran tentang pendidikan agama Islam di SMA Dua Mei tidak hanya dilakukan dalam pembelajaran Pendidikan Agama Islam (PAI) yang dilaksanakan di dalam kelas saja, tetapi penerapan nilai-nilai keagamaan juga diterapkan di luar kelas dengan kegiatankegiatan dalam rangka mengembangkan kecerdasan emosinya dengan pengendalian diri dan juga untuk mengembangkan kecerdasan spiritualnya dengan kegiatan yang dapat mendekatkan siswa dari segi keyakinan beragama.

“...Kegiatan yang dalam rangka menstabilkan emosinya ini kita lebih tanggap lagi atau mendekatkan lagi anak-anak itu tentunya mendekatkan diri dari segi keyakinan beragama yah, di sini kan mayoritas muslim sehingga program yang kita buat itu adalah dalam satu bulan hari jumat jam pertama kita mengadakan jumat mengaji bersama, yasin, tahlil, kemudian kita berdoa kemudian setelahnya ada sedikit ceramah lah untuk memberikan motivasi anak, kemudian pembiasaan-pembiasaan baik, shalat dzuhur berjamaah, kegiatan berinfaq setiap hari jum'at, pesantren kilat setiap bulan ramadhan, perayaan hari besar Islam, pembelajaran dan yah seperti itulah..."

Peneliti menganalisis dari penjelasan wawancara kepada bapak kepala sekolah, bahwa SMA Dua Mei memiliki berbagai macama kegiatan yang dapat mengembangkan self control (kontrol diri) siswa. Hal ini seperti yang telah disampaikan terdapat berbagai jenis kegiatan seperti Jum'at mengaji bersama, 
shalat berjama'ah, pesantren kilat ramadhan, perayaan hari besar Islam, kegiatan berinfaq dan lain sebagainya.

Adapun kegiatan keagamaan di sekolah SMA Dua Mei Ciputat dalam rangka mengembangkan pengendalian diri (self control) siswa adalah:

1. Shalat Dzuhur berjamaah

Pelaksanaan shalat dzuhur berjamaah dilaksanakan setiap hari sebagai salah satu cara untuk membiasakan siswa untuk mau shalat berjamaah dan siswa mengetahui pentingnya shalat berjama'ah.

2. Shalat Jum'at

Pelaksanaan shalat jum'at dilaksanakan setiap hari jum'at, ketika siswa diberi kebebasan melaksanakan shalat jum'at di masjid luar sekolah, pihak sekolah kesulitan mengatur kedisiplinan siswa. Hal ini untuk membiasakan siswa untuk berangkat shalat jum'at dengan datang lebih awal, melatih dan membiasakan siswa untuk bertanggung jawab sebagai penyelenggara shalat jum'at dan mengorganisisr masjid mulai dari menyediakan sound system, membersihkan masjid, meyiapkan karpet, menjadi muadzin, dan pelapor keuangan infaq sekolah.

3. Pesantren kilat ramadhan

Pelaksanaan Pesantren kilat ramadhan dilakukan pada bulan ramadhan untuk mengisi kegiatan selama bulan ramadhan. Kegiatan ini sebagai salah satu meningkatkan pemahaman, penghayatan dan pengalaman anak tentang ajaran Agama Islam, menerapkan dan mengamalkan ajaran Islam dalam kehisupan sehari-hari dalam rangka membentuk mental spiritual yang tangguh dan kokoh

4. Praktik Qurban

Setiap pelaksanaan hari raya qurban SMA Dua Mei melaksanakan penyembelihan hewan qurban, yang mana pelaksanaannya turut dibantu oleh siswa dan siswa yang berpartisipasi dari penyembelihan hewan qurban sampai pembagian daging qurban.

5. Praktik Jenazah

Peraktik jenazah dilaksanakan pada pada siswa SMA Dua Mei kelas XI, yang sesuai dengan materi pada pembelajaran PAI. Kegiatan ini sebagai salah satu kegiatan untuk memberikan pemahaman mengenai bagaimana mengurus jenazah mulai dari memandikan, mengkafani, menshalati, dan menguburkan.

6. Maulid Nabi

Pelaksanaan maulid nabi di SMA Dua Mei, sebagai salah satu kegiatan untuk menumbuhkan kembali kecintaan kepada Rasulullah saw. meneladani perilaku dan perbuatan Rasulullah saw kepada siswa.

7. Ceramah Agama

Pelaksanaan Ceramah agama dilakukan setelah kegiatan keagamaan setiap hari jum'at, ceramah agama ini sebagai salah satu cara untuk menambah keilmuan siswa tentang agama, sebagai sarana untuk memberikan motivasi kepada siswa.

8. Mengaji bersama pembacaan yasin, tahlil setiap hari jum'at 
Pelaksanaan mengaji bersama pembacaan yasin dan tahlil setiap hari jum'at. Kegiatan ini biasanya dilakukan di masjid sekolah. Tujuan kegiatan membaca yasin bersama-sama ini untuk memperdalam lagi siswa dan siswi membaca Al-Qur'an, selain itu juga agar seluruh siswa terbiasa membaca Al-Qur'an di sekolah.

9. Pengumpulan infaq setiap jum'at

Kegiatan pengumpulan infaq setiap hari jum'at biasanya dilakukan setelah mengaji bersama pembacaan yasin dan tahlil, bagi siswa yang bertugas nanti akan mengumpulkan infaq setiap kelas. Kegiatan ini dilakukan untuk mengajarkan anak untuk berinfaq dan bersedekah, kemudian untuk melatih empati anak kepada orang lain.

10. Jum'at bersih

Kegiatan Jum'at bersih dilakukan agar menjadikebiasaan yang baik dan menyehatkan dengan berbagai manfaat di antaranya menumbuhkan cinta dan peduli terhadap lingkungan sekolah, menumbuhkan rasa memiliki di kalangan siswa akan pentingnya kebersihan.

“...Sekolah ini sangat berpengaruh de, karena pembelajaran akan bisa maksimal apabila emosional anak itu bisa terkontrol dengan baik yah, kemudian anak-anak itu bisa dengan emosional yang stabil ia akan bisa lebih maksimal memahami, menerima materimateri yang dijelaskan oleh guru. Kalau bagaimana dia akan maksimal kalau kondisi siswa sendiri kurang terkontrol gitu yah, di sini peran guru lah yah bagaimana mengkondisikannya..."3

Peneliti menganalisis untuk tercapainya upaya untuk mengembangkan self control (kontrol diri) pada siswa, hal ini sudah didukung dengan berbagai macam kegiatan dan pembelajaran di sekolah, namun akan lebih maksimal lagi jika guru pun juga ikut berkontribusi dalam mengembangkan self control (kontrol diri) siswa.

Dalam proses pendidikan guru tidak hanya menjalankan fungsi alih ilmu pengetahuan (transfer of knowledge), tapi juga berfungsi untuk menanamkan nilai (values) serta membangun karakter (character building) peserta didik secara berkelanjutan. Guru dalam proses pembelajaran mempunyai peran yang sangat penting, bagaimanapun hebatnya perkembangan teknologi saat ini, peran guru tetap diperlukan.

Guru Pendidikan Agama Islam sangat berperan aktif dalam mengembangkan Self control (kontrol diri) siswa hal ini seperti yang disampaikan bapak kepala sekolah SMA Dua Mei:

"...Di sini sangat berperan sekali karena tidak mungkinyah tidak hanya untuk dirinya sendiri, ketercapaian kurikulum dari pemerintah itu yang pedoman pertama yah, yang kedua ada target sekolah ini harus ada nilai plus dari sisi religiusnya. Jadi kalau hanya kita punya kurikulum sesuai dengan aturan pemerintah pembelajaran PAI seperti ini nah kita harus ada lebihnya, gitu kan,... lebihnya itu apa, nah tadi ade sudah sampaikan bahwa pak jumaro mempunyai program seperti apa, pernah disampaikan ke saya, karena itu tentunya ada sebabnya, sebabnya itu jadi pemahaman anak-anak tentang baca tulis Qur'an ini tentang fenomena apa yah yang terjadi, kami kan terima kan dari SMP kan dari 
sekolah lain kan. ketika masuk ke sekolah kami di sini grade nya bertahap ada yang istilahnya yah baru iqro satu, iqro dua, nah seperti itu yah, nah demikian itu anak-anak kita di sini sehingga guru PAI memasukan materi pembelajaran sesuai dengan materinya di sini agak sedikit kesulitan, bagi anak-anak yang tadi ya untuk memahami tadi dari sisi baca tulis Qur'an, nah di sini lah program yang tadi yah bagaimana kita untuk mempercepat anak inibisa menguasai surat-surat pendek dan sebagainya yah, karena itu kan dasar sekali yah untuk pembelajaran berikutnya, nah itu yang kami lakukan seperti itu..."

Peneliti menganalisis bahwa guru Pendidikan Agama Islam (PAI) di SMA Dua Mei sangat memperhatikan bagaimana kemampuan siswa nya. Hal ini seperti disampaikan bapak kepala sekolah SMA Dua Mei bahwa guru Pendidikan Agama Islam (PAI) mempunyai program untuk mengembangkan kemampuansiswa baik dari segi pengetahuan agama maupun dari segi perilaku.

Kegiatan keagamaan yang ada di SMA Dua Mei dilaksanakan dengan kerjasama antara sekolah, guru dan siswa. Adapun upaya-upaya yang dilakukan oleh guru Pendidikan Agama Islam (PAI) di SMA Dua Mei dalam mengembangkan self control (kontrol diri) siswa yaitu sebagi berikut:

a. Upaya yang dilakukan guru Pendidikan Agama Islam (PAI) dalam mengembangkan aspek cognitive control (kontrol pengetahuan) pada siswa

Dalam mengembangkan aspek cognitive control atau kontrol pengetahuan siswa, hal ini dapat dikembangkan dengan memperbanyak informasi keagamaan yang diperoleh siswa. Guru Pendidikan Agama Islam (PAI) melakukannya dengan memberikan pembelajaran Pendidikan Agama Islam (PAI) dan beberapa penerapan pembiasaan baik di kelas guna mengembangkan self control (kontrol diri) siswa, yaitu dengan membiasakan siswa tepat waktu ketika masuk kelas agar disiplin, kemuadian membaca surat-surat pendek sebelum memulai pembelajaran, kemudianmengajak siswa berdiskusi dengan melihat masalah yang ada di sekitar lingkungan guna menumbuhkan rasa empati dan menambah pengetahuan, kemudian siswa menyampaikan nya di depan kelas untuk menumbuhkan rasa peracaya diri siswa.

"...ya kalo di kelas itu saya mulai dengan membaca surat-surat pendek sebelum memulai kegiatan belajar mengajar, kemudian melatih siswa untuk melihat masalah di sekitar kita kemudian mendiskusikan dan menarik kesimpulan serta hikmah dari masalah itu kemudian membiasakan siswa terlatih menyampaikan diskusi di depan kelas, kalau di dalam RPP kan itu adayah siswa di ajarkan untuk membidik di sekitar kita, kemudian disiplin dalam waktu...,5

Seperti yang telah disampaikan, peneliti menganalisis bahwa guru Pendidikan Agama Islam (PAI) di SMA Dua Mei Ciputat telah memberikan informasi lebih tentang materi Pendidikan Agama Islam (PAI) yaitu dengan melatih siswa untuk melihat masalah di sekitar sehingga siswa dapat menerima informasi lebih mengenai pembelajaran Pendidikan Agama Islam yang dikaitkan dengan kehidupan di sekitarnya.

b. Upaya yang dilakukan guru Pendidikan Agama Islam (PAI) dalam mengembangkan Behavior Control (Kontrol Perilaku) pada siswa dalam 
mengembangkan aspek behaviorcontrol atau kontrol perilaku siswa, hal ini dapat dikembangkan dengan memberikan stimulus melalui pembiasaan-pembiasaan baik kepada siswa serta memberikan contoh teladan yang baik untuk siswa. Guru Pendidikan Agama Islam (PAI) melakukannya dengan menunjuk siswa yang sudah mampu sebagi muadzin dan imam shalat, hal ini dilakukan untuk memberikan pembiasaan baik yang nanti akan berguna di keluarga dan masyarakat. Selain itu juga guru Pendidikan Agama Islam (PAI) berusaha memberikan contoh yang baik dengan ikut shalat berjamaah dengan siswa, dan berkontribusi pada setiap kegiatan keagamaan yang ada di sekolah.

"Saya biasa menunjuk siswa untuk menjadi muadzin dan imam untuk memberikan pengalaman kepada siswa yang menurut saya sudah mampu untuk menjadi imam dan muadzin, kemudian saya juga berusaha memberikan contoh yang baik dengan ikut sholat berjamaah bersama siswa, mengikuti setiap kegiatan keagamaan di sekolah serta berkontribusi dalam acara tersebut. Kalau kegiatan keagamaan di sekolah banyak sih, setiap perayaan hari besar Islam pasti sekolah mengadakan, kemudian kegiatan yasin dan tahlil setiap hari jumat juga..."

Peneliti menganalisis bahwa guru Pendidikan Agama Islam (PAI) di SMA Dua Mei Ciputat ini sangat berkontribusi dalam mengembangkan self control (kontroldiri) pada siswadi sekolah. Hal ini dapat dilihat bahwa selain aktif pada pembelajaran Pendidikan Agama Islam (PAI) di dalam kelas, guru Pendidikan Agama Islam (PAI) juga aktif dalam kegiatan sekolah yang dilakukan diluar kelas. Berikut hasil wawancara siswa mengenai kontribusi guru Pendidikan Agama Islam (PAI) dalamn mengembangkan Self control ( Kontrol diri) siswa di sekolah.

"...kan biasanya sih ka kalau ada acara keagamaan kan biasanya beliau suka ngambil alih terlebih dahulu gitu ka, beliau suka mimpin yasinan sih biasanya, terus mimpin doa bersama juga, beliau juga suka nyuruh anak jadi muadzin dan imam, beliau juga sholat jamaah..."

“...ia beliau suka mimpin yasinan, terus juga suka bantu-bantu ngatur anak-anak baris kalau misalnya mau ke masjid gitu, mau tausyiah, atau beliau juga yang mimpin shalawat..."

“...Bapak sering ngajak anak-anak buat sholat dzuhur berjamaah, terus kaya jumat yasinan itu biasanya bapak juga sering keliling kelas buat nyruh kumpul buat yasinan dan bapak juga yang mimpin yasinan..."

Dari penjelasan dari wawancara beberapa siswa dan siswi SMA Dua Mei ini dapat dibuktikan bahwa guru Pendidikan Agama Islam (PAI) di SMA Dua Mei sangat berkontribusi dalam mengembangkan self control (kontrol diri) siswa di sekolah.

c. Upaya yang dilakukan guru Pendidikan Agama Islam (PAI) dalam mengembangkan Decision Control (Kontrol keputusan) pada siswa 
Dalam mengembangkan aspek Decision Control atau Kontrol keputusan pada siswa, hal ini dapat dikembangkan dengan memberikan suatu kesempatan, kebebasan atau kemungkinan pada diri siswa untuk memilih berbagai kemungkinan tindakan. Guru Pendidikan Agama Islam (PAI) mengembangkan kontrol keputusan siswa dengan memberikan siswa kesempatan berbicara pada saat berdiskusi di kelas, siswa dilatih untuk dapat menyampaikan pendapatnya yang kemudian diberikan arahan oleh guru Pendidikan Agama Islam (PAI).

"melatih siswa untuk melihat masalah di sekitar kita kemudian mendiskusikan dan menarik kesimpulan serta hikmah dari masalah itu kemudian membiasakan siswa terlatih menyampaikan diskusi di depan kelas"

Guru Pendidikan Agama Islam (PAI) di SMA Dua Mei juga memiliki program untuk siswa yang menurutnya masih kurang yang mana harus dibimbing lagi dalam hal perilaku dan siswa yang kurang dalampengetahuan agama Islam nya.

“...Saya punya program baru, jadi nanti siswa yang agak kurang pemahaman tentang agamanya nanti akan kita bina dan dididik di sekolah, nanti saya ajarkan, jadi nanti selama 24 jam berada di sekolah. Tapi tentu dengan persetujuan orang tua mereka karena kan nanti akan ada akomodasinya seperti biaya makan dan lainnya selama tinggal di sekolah..."

Peneliti menganalisis bahwa guru Pendidikan Agam Islam (PAI) memiliki peran yang cukup banyak dalam membimbing siswa baik dari segi perilakunya dan juga dari segi pengetahuan nya tentang agama Islam, hal ini tentu sangat berpengaruh terhadap perkembangan self control (kontrol diri) pada siswa.

d. Faktor penghambat dan pendukung dalam mengembangkan self control (kontrol diri) siswa

"...Kalau untuk faktor penghambat dan pendukung yah itu lebih kembali kepada siswa itu sendiri,karena kan setiap anak kan beda-beda yah, ada yang memang mau di atur jadi dia perkembangannya lebih bagus dibanding siswa yang memang agak sulit untuk diatur dan diarahkan..."

Faktor penghambat dan pendukung dalam mengembangkan self control (kontrol diri) siswa ada karena siswa adalah individu yang berbeda-beda, menjadi sebuah penghambat jika siswa yang dibimbing agak sulit untuk mengikuti arahan atau bimbingan guru PAI, namun jika siswa yang mau mengikuti arahan guru PAI tentu akan lebih banyak perkembangannya dibanding dengan siswa yang agak sulit untuk dibimbing.

e. Pengaruh dari upaya guru Pendidikan Agama Islam (PAI) dalam mengembangkan self control (Kontrol diri) pada siswa

Upaya-upaya yang dilakukan guru Pendidikan Agama Islam (PAI) dalam mengembangkan self control (Kontrol diri) pada siswa tentu akan mempunyai pengaruhterhadap perkembangan self control (Kontrol diri) siswa.

“...Jika efektif atau tidaknya saya pun belum tau, karena saya belum melakukan penelitian mengenai program-program tersebut, namun 
sejauh ini tentu ada sedikit banyaknya perubahan yang terjadi pada siswa, karena kan yang nama nya sudah berupaya pasti kan akan ada perubahan nya. Tapi yah sejauh ini siswa sudah alhamdulillah dari sebalumnya..."

Peneliti menganalisis bahwa upaya-upaya yang telah dilakukan oleh guru Pendidikan Agama Islam (PAI) dalam mengembangkan self control (kontrol diri) siswa sudah mempunyai pengaruh yang baik terhadap siswa, halini dibuktikan dari wawancara yang telah dilakukan oleh peneliti terhadap siswa SMA Dua Mei.

“...Kalau dampaknya sama diri aku sendiri sih, gara-gara bapak sering ngasih soal dan suka ngasih hafalan terus saya jadi kaya nyadar kalau ternyata ngafalin tuh seru juga, terus jadi percaya diri juga karena sering nyuruh presentasi. Jadi saya juga jadi pengen memperdalam agam gitu sih ka..."

“... Ada sih ka sedikit-sedikit mah, kaya akunih ka yang gak biasa ngomong di depan kan karena presentasi aku jadi bisa belajar gitu jadi bisa, terus juga bapak yang ngingetin buat sholat dzuhur berjamaah itu juga jadi ngingetin gitu ka gitu, jadi sadar gitu langsung ke masjid kalau udah azan, terus juga kaya jumat yasinan juga saya jadi sudah langsung ke masjid gitu ka tanpa di suruh..."

Dari hasil wawancara yang dilakukan peneliti kepada siswa SMA Dua Mei, upaya yang dilakukan oleh guru Pendidikan Agama Islam (PAI) dalam mengembangkan self control (kontrol diri) siswa sudah cukup efektif dan mempunyai pengaruh terhadap siswa hal ini seperti yang sudah disampaikan siswa bahwa pembiasaan yang diterapkan sudah mempunyai perubahan yang positif terhadap siswa. Siswa memiliki pengalaman dengan terbiasa menjadi muadzin dan imam, siswamemiliki kesadaran dalam beribadah tanpa ada paksaan dari guru PAI, siswa memiliki rasa percaya diri, dan membuat siswa menjadi lebih tertarik untuk memperdalam ilmu agama.

Hasil dari penjelasan analisis di atas, maka peneliti menyimpulkan bahwa guru Pendidikan Agama Islam (PAI) sudah sangat berkontribusi dalam mengembangkan self control (kontrol diri) siswa di SMA Dua Mei Ciputat. Hal ini dapat dilihat bahwa guru PAI sudah berupaya dalam mengembangkan setiap aspek dalam self control (kontrol diri) yaitu dengan memberikan informasi mengenai pengetahuan tentang agama Islam serta memberikan pembiasaanpembiasaan baik kepada siswa. Guru PAI di SMA Dua Mei juga selalu berkontribusi pada setiap kegiatan keagamaan di sekolah, kemudian guru PAI di SMA Dua Mei juga menerapkan pembiasaan-pembiasaan baik pada saat pembelajaran PAI di dalam maupun di luar kelas.

\section{KESIMPULAN}

Berdasarkan analisis penelitian, maka peneliti menyimpulkan bahwa guru Pendidikan Agama Islam (PAI) di SMA Dua Mei Ciputat sudah cukup berkontribusi dalam mengembangkan self control (kontrol diri) siswa di SMA Dua Mei Ciputat. Hal ini dapat dilihat bahwa guru PAI sudah berupaya dalam mengembangkan setiap aspek dalam self control (kontrol diri) yaitu Aspek kontrol pengetahuan (cognitive control) dengan memberikan informasi lebih mengenai pengetahuan tentang agama Islam dengan cara mengintegrasikan materi pembelajaran PAI dengan keadaan sekitar, kemudian aspek kontrol perilaku 
(behavior control) guru PAI memberikan pembiasaan baik kepada siswa di dalam maupun di luar kelas, seperti disiplin, membiasakan siswa shalat berjamaah, serta aspek kontrol keputusan (decision control) yaitu siswa diberi kesempatan untuk berpendapat pada saat diskusi yang dilakukan dengan bimbingan guru PAI, guru PAI juga memberikan bimbingan dan arahan kepada siswa yang melanggar peraturan sekolah.

Dari berbagai kontribusi guru PAI tentu sangat berpengaruh terhadap perkembangan self control (kontrol diri) siswa, hal ini dapat dilihat dari pembiasaan yang diterapkan oleh guru PAI dapat memberikan perubahan yang positif terhadap siswa, seperti siswa memiliki pengalaman dengan terbiasa menjadi muadzin dan imam, siswa memiliki kesadaran dalam beribadah dan mengikuti kegiatan keagamaan tanpa ada paksaan dari guru PAI, siswa memiliki rasa percaya diri, dan membuat siswa menjadi lebih tertarik untuk memperdalam ilmu agama Islam. 


\section{DAFTAR PUSTAKA}

Dwi Laning, Vina. 2018. Kenakalan Remaja dan Penanggulangannya. Klaten: Penerbit Cempaka Putih.

Dwi Marsela, Ramadona. 2019. Kontrol diri Definisi dan Faktor, Vol.3, No.2, Agustus, lih. http://journal.umtas.ac.id/index.php/innovative counseling

Noor, Juliansyah. 2011. Metodologi Penelitian. Jakarta: Kencana.

Rukin, 2019. Metodologi Penelitian Kualitatif. Takalar: Yayasan Amhar Cendekia Indonesia.

Rusdiyanti, Ivong. 2019. Faktor-Faktor yang Melatarbelakangi Kenakalan Pada Remaja di Yayasan Wagas Limpua Banjarmasin, Vol. 3, No, lih. journal.umbjm.ac.id/index.php/healty

Sanjaya, Wina. 2013. Penelitian Pendidikan: Jenis, Metode dan Prosedur. Jakarta: Kencana.

Syaodih Sukmadinata, Nana. 2013. Metode Penelitian Pendidikan. Bandung: PT Remaja Rosda Karya.

Undang-undang Nomor 14 Tahun 2005 tentang Guru dan Dosen pada pasal 10 ayat (1)

Universitas Psikologi, "Pengertian Self Control dan Aspek-Aspek Self Control Menurut Para Ahli”, 24 Maret 2020, lih https://www.universitaspsikologi.com/2020/03/pengertian-self- controldan-aspek-aspek-kontrol-diri.html?m=1

UU SISDIKNAS No.20 Tahun 2003 Pendidikan Nasional

Wayan Suwendra. 2018. Metode Penelitian Kualitatif. Badung Bali: Nilacakra.

Zubaedi, 2013. Desain Pendidikan Karakter Konsepsi dan Aplikasinya dalam Lembaga Pendidikan. Jakarta: Kencana. 